\author{
Magyar Honvédség Egészségügyi Központ \\ Plasztikai és Égéssebészeti Osztály
}

\title{
Újdonságok az égéssebészetben
}

\section{Dr. Halmy Csaba orvos ezredes}

Kulcsszavak: égési sokk, sokktalanítás, enzimatikus nekrektómia, bőrpótlás

\begin{abstract}
A szerző bemutatja az égési sokk kezelésének vitatott pontjait és a jelenleg elfogadott módszereket, ismerteti az enzimatikus nekrektómia új lehetőségét, valamint a kiterjedt bőrhiány ideiglenes és végleges fedésének korszerü lehetőségeit
\end{abstract}

Az égésbetegség kezelésének sok ma is vitatott - tehát megoldatlan - területe van. Polémia zajlik a folyadékpótlásról, az égési sokk kezelése kapcsán is. Több szerzői formula alapján történik a krisztalloid/kolloid infúziós terápia, valamint annak monitorizálása is. Egyre világosabb azonban, hogy minden egyes betegnél a különböző formulák csak tájékozódó információt és segítséget adnak. A kezelést mindig az adott beteghez kell individualizálni, függően a páciens kardiopulmonális státuszától, vesefunkciójától, stb.

$\mathrm{Az}$ égett területek sebészi kezelése is folyamatosan megújul. Az egészségipar újabb és újabb termékeket állít a gyógyítás szolgálatába. Érdemes bemutatni a nekrektomiára ajánlott enzimatikus debridement módszerét, hisz akár egyéni, de még inkább tömeges ellátás során felgyorsíthatja és egyszerüsítheti a közepes és súlyos égési sérülések sebészi ellátását.
A bőrpótlás területén is egyre több, korszerübb módszerrel és anyaggal találkozunk. A cikkben igyekszem ráirányítani a figyelmet a micrografting transzplantációs technikára, illetve a bioszintetikus, modern bőrpótló anyagok használatára.

\section{Az égési sokk kezelése}

A testfelszín több mint 20\%-át érintő sérülés esetén kiterjedt vagy súlyos égési sérülésről beszélünk, mert körülbelül ez az a határ, amely fölött a termikus trauma által kiváltott gyulladásos reakció az egész szervezetet érintő, szisztémás gyulladáshoz vezet. A szisztémás gyulladásos válasz egyik első szövődménye az égési sokk. Bár hipovolémiás sokk, patomechanizmusa a szeptikus sokkéhoz hasonlít, mert kialakulásáért a gyulladásos mediátorok felelősek. Az égési sokk legfontosabb eleme a pulzus- és követ- 
kezményesen perctérfogat csökkenéshez vezető plazmavesztés az intersticiális térbe („fehér vérzés”). Fontosnak tartjuk hangsúlyozni, hogy kiterjedt égési sérülést szenvedőknél a vérnyomás normális vagy magas lehet, ezért a sokkindex nem használható. 20\% feletti kiterjedés esetén a sokktalanítást haladéktalanul meg kell kezdeni $[1,2]$.

A sokktalanítás célja a szövetek perfúziójának helyreállítása a minimálisan szükséges folyadék mennyiségével. Az elégtelen folyadékbevitel szervelégtelenséghez vezet, a túlzott folyadékbevitel tüdöödémát, kompartment szindrómát és az égési sérülés kimélyülését okozhatja. Az égési sokk ismerete és kezelése csaknem száz évre tekint viszsza [3], mégis a legfontosabb kérdéseket illetően ma sem egységes a szakma. Vitatott a folyadékszükséglet optimális kiszámításának módja, ismét fellángolt a krisztalloid/kolloid vita, és nincs egységes álláspont a sokktalanítás monitorizálását illetően.

A képlet-alapú sokktalanítás csaknem teljesen általános az égési sérülteket ellátó centrumokban. A leggyakrabban alkalmazott képletek a Parklandés a módosított Brooke-formula, mindkettő széles körben elfogadott. A sérüléstől az első 24 óráig számított folyadékszükséglet a Parkland-formula szerint $4 \mathrm{ml} / \mathrm{ttkg} / \mathrm{TBSA} \%$ (égett testfelszín \%), a Brooke-formula szerint $2 \mathrm{ml} /$ ttkg/TBSA\%, amelynek a felét az első 8 órában, második felét az ezt követő 16 órában kell beadni [2]. A számított folyadékbevitel mindkét esetben csak útmutatóul szolgál, a tényleges folyadékbevitelt valamilyen élettani paraméter (pl. óradiurézis) alapján szükség esetén módosítani kell. A Parkland-formula megalkotása óta tudjuk, hogy bizonyos betegcsoportok ennél jóval nagyobb mennyiségű folyadékpótlást igényelnek, így például légúti égés, későn kezdett sokktalanítás, politrauma vagy alkoholfogyasztás növeli a sokktalanításhoz szükséges folyadékmennyiséget, akár 9 $\mathrm{ml} / \mathrm{ttkg} / \mathrm{TBSA} \%$ fölé [3].

$\mathrm{Az}$ Amerikai Hadsereg Égési Centrumának munkatársai az Irakból és Afganisztánból hazaszállított égési sérültek sokktalanítását vizsgálva azt találták, hogy Parkland-formula szerint kezdett sokktalanítás esetén az első 24 óra folyadékszükséglete $5,9 \pm 1,1 \mathrm{ml} /$ ttkg/TBSA\%, módosított Brooke-formula szerint indított sokktalanításnál 3,8 $\pm 1,2 \mathrm{ml} / \mathrm{ttkg} / \mathrm{TBSA} \%$ volt, azonos óradiurézis célérték mellett. Azt a következtetést vonták le, hogy a nagyobb kezdeti folyadékbevitel a sokktalanítás későbbi fázisában is nagyobb folyadékmennyiséget igényel [4].

Bár a nemzetközi ajánlások alapján azonos értékünek tűnik mindkét formula (illetve a kettő közötti bármely érték), az irodalomban egyre több adatot találunk az általánossá váló túlzott folyadékbevitelről (over-resuscitation), ezért megfontolandó a szakmai szempontból helyesnek ítélt, ugyanakkor fele mennyiséggel indító módosított Brooke-sémára áttérni.

$\mathrm{Az}$ Amerikai Hadsereg Égési Centrumában egy új folyadékszükséglet számítást dolgoztak ki, amelyet mind a kórházban, mind a hadszíntéren alkalmaznak [5]. A 10-es szabálynak nevezett formulát 2016-ban egy Landstuhlban szervezett Advanced Burn Life Support Provider Course keretében ismertem meg. 40 és $80 \mathrm{~kg}$ testtömeg között a kezdő folyadéksebesség az égett testfelszín százalék tízszerese, ml/órában. $80 \mathrm{~kg}$ fölött minden $10 \mathrm{~kg}$ súlytöbblet a sebesség növelését jelenti 100 ml/órával. Kiszámítása egyszerü, az eredmény jellemzően a 
Brooke- és a Parkland-formula által adott érték közé esik, ezáltal elkerülhetővé válik a túlzott folyadékbevitel.

A túlzott folyadékbevitel eredményét Pruitt „folyadék kicsúszás”-nak (fluid creep) nevezte el. Ez részben azt jelenti, hogy nagy mennyiségü folyadék jut ki a keringésből a szövetek közé, de azt is jelenti, hogy a sokktalanítás kicsúszott a kezünkből. A fluid creep szövődménye lehet generalizált ödéma, tüdőödéma, akut tüdőkárosodás/ akut respirációs distressz-szindróma, az égési sérülés kimélyülése, végtagi kompartment szindróma, másodlagos abdominális kompartment szindróma, orbitális kompartment szindróma. Kialakulásának kockázata jelentősen megnő $6 \mathrm{ml} / \mathrm{ttkg} / \mathrm{TBSA} \% / 24$ óra folyadékbevitel felett, vagy az úgynevezett Ivy index, $250 \mathrm{ml} / \mathrm{kg} / 24$ óra folyadékbevitel elérése esetén [3].

Kialakulásában számos tényező játszhat szerepet. A Parkland- és Brooke-formulák megalkotásakor a cél az akut veseelégtelenség megelözése volt, amellyel ma már ritkán találkozunk, azonban sok olyan beteget sokktalanítunk, akik Baxter idejében nem voltak megmenthetők és a folyadékszükségletük lényegesen nagyobb, mint a Parkland-képlet által meghatározott mennyiség. Ugyanakkor az is ismert, hogy az első ellátók az égési sérülés kiterjedését gyakran túlbecsülik, továbbá az égési centrumba érkezésig a betegek a számított napi folyadékszükséglet jelentős részét már megkapják, amely a továbbiakban is megnövekedett folyadékigényt jelent. Szintén ismert jelenség, hogy míg elégtelen óradiurézis mellett a folyadékbevitel sebességét készek vagyunk növelni, a kívántnál magasabb óradiurézis ritkán eredményezi a folyadékbevitel csökkentését [3].
Bár eredetileg Baxter a sokktalanítás utolsó 8 órájában a Parkland-séma részeként plazma adását javasolta, és az első Brooke-formula is részben kolloidra épült, a későbbiekben a kolloid adását világszerte mellözték annak felismerése alapján, hogy kizárólag krisztalloiddal is lehetséges a sokktalanítás. A jelenleg általánossá váló túlzott folyadékbevitel elkerülése céljából azonban ismét egyre elfogadottabbá válik a sokktalanítás kiegészítése kolloid oldattal a 8-12. órától. Ez elsősorban sikertelen sokktalanítás, a testfelszín több mint felét érintő sérülés, gyermek- és időskorban indokolt. Kolloid oldat alkalmazása a fluid creep megelözése céljából mindenképpen indokolt, ha a 12. órában számolt, várható 24 órás folyadékbevitel meghaladja az Ivy-indexet. Optimális kolloid oldatnak jelenleg az 5\%-os humán albumin tünik, bár számos centrumban friss fagyasztott plazmát használnak [6].

Fluid creep kialakulásához vezethet a korszerű, invazív mérésekkel meghatározott célértékek alapján vezetett sokktalanítás is. Bár egyes munkacsoportok ezt tartják követendőnek, más szerzők nem látják igazoltnak és változatlanul az óradiurézis követését javasolják a folyadékbevitel sebességének meghatározásához [1].

\section{Enzimatikus debridement}

2012-ben Nexobrid néven (Mediwound GmbH, Németország) egy új, növényi enzim-alapú készítmény került Európában forgalomba az égési sebek enzimatikus feltisztítása céljából. A Nexobrid hatóanyaga az ananásznövény szárából kivont bromelain [7].

Több mint 500 kezelés tapasztalata alapián egy neves szakértőkből álló európai munkacsoport 2017-ben 
konszenzus dokumentumot publikált [8]. Szakértői vélemény és a rendelkezésre álló irodalmi adatok alapján a készítménnyel végzett débridement számos előnnyel jár a hagyományos sebészi nekrektómiához képest. Az enzim fontos tulajdonsága, hogy szelektív nekrektómiát végez, csak az elhalt szöveteket távolítja el. Ezzel szemben a tangenciális excízió során jelentős mennyiségü ép szövet is áldozatul esik. További előnye, hogy enzimatikus nekrektómia után nagyobb arányban jön létre spontán hámosodás, mint kimetszés után, így csökken a bőrátültetést igénylő sebek száma. A kezelés kisebb vérvesztéssel, gyorsabb feltisztulással és gyógyulással jár, mint a sebészi kezelés. A tapasztalat azt mutatja, hogy a mély másodfokúnak vagy harmadfokúnak ítélt, és mütéti indikációt (kimetszés+bőrátültetés) jelentő sebek enzimatikus feltisztítása után a sebek gyakran felületesebbnek bizonyulnak, és a szelektív nekrektómia után megmaradó életképes irharéteg spontán hámosodást tud biztosítani. Enzimatikus kezelést követően a funkcionális és esztétikai eredmények a sebészi kezelés eredményeivel azonosnak bizonyultak $[9,10]$.

A Nexobrid alkalmazása egy összetett kezelés. A seb mechanikai tisztítását követően nedves kötéssel kell a sebfelszínt előkészíteni, a környezetet vazelinnel vagy stóma pasztával védeni, majd a kenőcsöt 1,5-3 mm vastagságban felvinni és okkluzív kötéssel fedni. Az enzim hatásának kifejtéséhez 4 óra szükséges, ezt követően ismételt sebtisztítást kell végezni és nedves kötést felhelyezni. A további kezelés a kenőcs eltávolítása után dönthető el. Konzervatív kezelés választása esetén a teljes hámosodásig szükséges a nedves környezet biztosítása, erre elsősorban Suprathelt vagy allograftot javasolnak. Az enzimatikus débridement után egyértelműen mélynek ítélt sebeken bőrátültetés indokolt. Az enzimes kezelés erős fájdalommal jár, ezért szedációval, analgoszedációval kell kiegészíteni. A készítmény engedélye felnőttekre és a testfelszín kisebb mint 15\%-ának kezelésére szól, azonban jó tapasztalatok vannak gyermekek kezelésében és a testfelszín akár 30\%-án történő alkalmazással is [7].

\section{Meek mikrografting}

A részvastag bőrgraft méretének növelésére általánosan alkalmazott eljárás a rácsozás vagy hálósítás. Ez különös jelentőséggel bír kiterjedt égési sérülésben, ahol korlátozott a rendelkezésre álló adóterület. A rácsozás és nyújtás aránya 1:1-től 1:9-ig lehetséges. 1:3-4 arány felett azonban a graft kezelhetetlenné, transzplantálhatatlanná válik. A hálósítási arány növelésével a rácsközök egyre nagyobbakká, a rácsközök széleit képező bőrcsíkok egyre vékonyabbá válnak. A cérnavékony bőrcsíkok szakadékonyak és a hámfelszín befordulása miatt nem biztosítják az irharéteg sebfelszínre történő felfekvését.

Ennek kiküszöbölésére Meek 1958ban javasolta az apró bélyegekkel végzett mikrotranszplantációs techniákát, amelynek továbbfejlesztése Kreis nevéhez füződik (1993). Jelenleg a meektechnika alkalmazását a holland Humeca cég speciális hálósító eszköze és rendszere biztosítja világszerte és az utóbbi években egyre elterjedtebbé válik [11].

A módszer lényege, hogy $42 \times 42 \mathrm{~mm}$ es parafa lapokra kell a részvastag graftot felvinni, úgy hogy az irhafelszín fekszik a lapra. A Meek-hálósítóba egyszerre két kocka helyezhető. A vágást az egyik, majd 90 fokban elfordítva arra merőleges 
irányban végzi 13 , egymástól $3 \mathrm{~mm}$-re elhelyezett penge. Így az első vágás után $14 \mathrm{db} 3 \mathrm{~mm}$-es csík jön létre, a második vágás után $196 \mathrm{db}$ négyzet alakú bőrsziget. Ekkor a hámfelszínt adhezív sprayjel kell befújni és egy speciálisan kialakított poliamid hordozó hálóra ragasztani. A későbbi manipuláció megkönnyítése érdekében a poliamid hálót egy vékony alumínium lemez erősíti. Néhány perc várakozás után a parafa lemez eltávolítható. A hordozó felületet mindkét irányba megfeszítve, a teljes kisimulásig, a hámszigetek eltávolodnak egymástól. A hálósítás és nagyítás mértékét a hordozó eredeti hajtogatása határozza meg. $1: 3,1: 4,1: 6$ és $1: 9$ arányú nagyítást biztosító hordozók választhatóak.

$\mathrm{Az}$ irodalmi adatok szerint a meektechnikával végzett transzplantáció megtapadási aránya $80 \%$ feletti és egy műtét során akár a testfelszín több mint 40\%-ának fedését is biztosítani tudja, így kiválthatja a költséges és bizonytalan eredményü keratinocita tenyésztést. $\mathrm{Az}$ optimális eredmény elérése céljából, mély égési sérülés esetén a sebalap allografttal történő előkészítését javasolják. Kreis módosítása szerint a poliamid háló eltávolítása után (7-10. nap) szintén allografttal történő fedés célszerű a teljes hámosodásig [12,13].

\section{Bioszintetikus bőrpótló anyagok}

A bőrhelyettesítő anyagok területén világszerte intenzív kutatás folyik, és korábbi összefoglalónk [14] óta számos érdekes eredmény született. Ezek közül kiemelendő a hámfelszín ideiglenes helyettesítésére szolgáló Suprathel és a teljes vastagságú bőrhiányok végleges pótlására kifejlesztett autológ, kétrétegü tenyésztett bőr.
A Suprathel (PolyMed Innovations Gmbh, Németország) egy vékony, tejsav polimérből álló membrán, amely a hámréteg ideiglenes helyettesítésére szolgál. Kiválóan alkalmazható másodfokú (felületes és átmeneti mélységü) égési sérülés, illetve a részvastag bőrgraft adóterületének konzervatív kezelésére. Sikeresen alkalmazták gyermek és felnőtt sérülteknél, sőt egy 80 éves betegen a testfelszín $51 \%$-át érintő másodfokú égési sérülés kezelésében is, ahol a hámhiány $97 \%$-a 14 nap alatt gyógyult $[15,16]$.

A seb feltisztítását követően a Suprathel, enyhe nyújtás mellett, könynyen felhelyezhető a sebfelszínre, amelyen nedvesség hatására rövid időn belül rögzül. Jól modellálható, ezért inkongruens felszíneken is alkalmazható. Porozitása biztosítja a sebváladék távozását, a membrán alatt nem alakul ki fertőzésveszélyt jelentő váladékretenció. A Suprathel a felhelyezést követően azonnali fájdalommentességet biztosít és a teljes hámosodásig fennmarad a seben, hámosodást követően pergamenszerűen leválik. Fedésére impregnált lap és gézlapok szükségesek, a fedőkötést a gyógyulásig néhány alkalommal cserélni kell. Kötéscsere alkalmával a membrán áttetszőségének köszönhetően a sebalap ismételten megítélhető, a kezelés nyomom követhetö. Az 1-6. áb$r a$ kéz felületes másodfokú égési sérülésének kezelését mutatja osztályunkon. Suprathel kezeléssel tíz nap alatt teljes hámosodást értünk el.

A Suprathel a felületes bőrhiányok konzervatív kezelésével szemben támasztott korszerü követelményeknek minden szempontból eleget tesz. Alkalmazásával más kezelési lehetőségekhez képest szignifikáns fájdalomcsökkenés érhető el, kevesebb kötéscserére van szükség, és kényelmesebb mind a keze- 


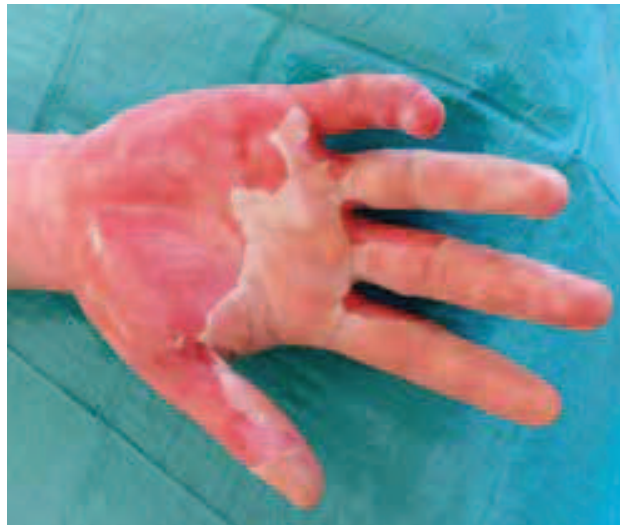

1. ábra. Forrázás által okozott tenyéri hámhiány

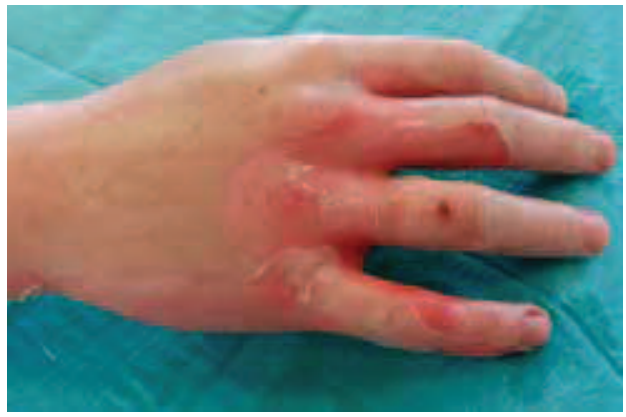

2. ábra. Hámhiány a kézháton

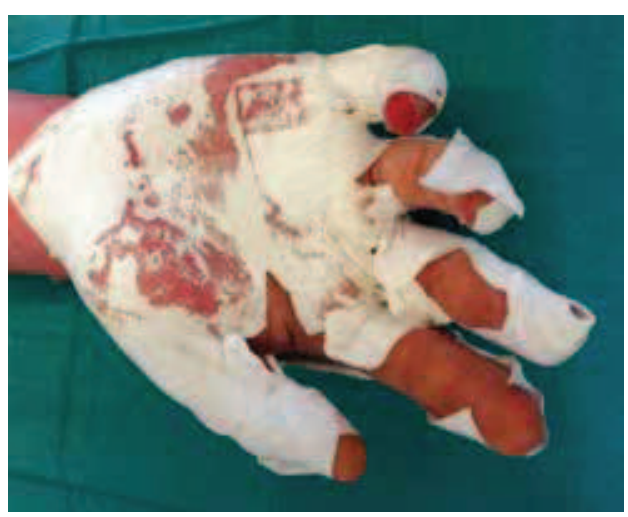

3. ábra. Fedés Suprathellel

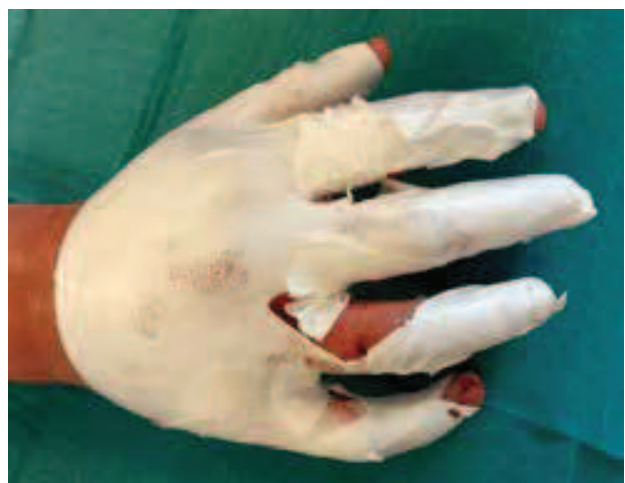

4. ábra. Fedés a kézháton

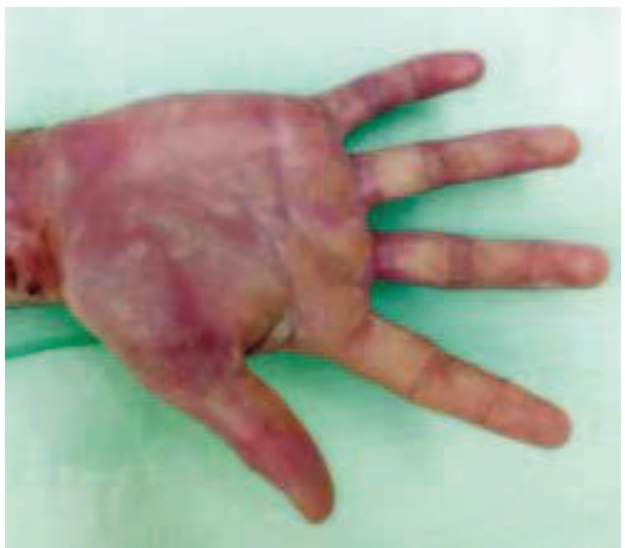

5. ábra. Teljes gyógyulás a 12. napon

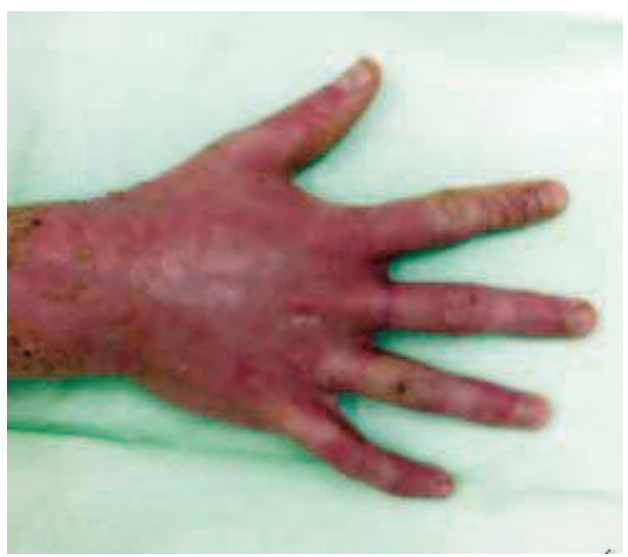

6. ábra. Hámosodott kézhát a 12. napon 
lőszemélyzet, mind a beteg számára. Tekintettel arra, hogy nem állati vagy humán eredetü, nem jelent betegségátviteli kockázatot, illetve alkalmazását nem korlátozhatja vallási megfontolás. Bár az egyszeri bekerülési ára meghaladja más, azonos indikációban használt termékek árát, a teljes kezelési költség figyelembevétele esetén költséghatékonynak bizonyult. A teljes kezelés és gyógyulási folyamat során biztosított fájdalommentesség miatt a közeljövőben rendkívüli szerepe lehet gyermekek másodfokú égési sérüléseinek kezelésében $[17,18]$.

Kiterjedt, mély égési sérülés kezelésénél az adóterület hiánya miatt rendkívüli kihívást jelent a bőrhiány pótlása. Bár az autológ tenyésztett keratinociával történő fedést az élenjáró égési centrumok több mint 30 éve sikeresen alkalmazzák és a módszer életmentő eljárásnak tekinthető, súlyos problémát jelent az irharéteg hiánya. Intenzív kutatás folyik az irharéteg és a hám egyidejü pótlásának megoldásáért. Rendkívüli eredményt ért el ezen a téren egy kanadai munkacsoport „kétrétegü, önépített bőrhelyettesíto"' (bilayered selfassembled skin substitute) előállításával. Munkájuk alapját az a megfigyelés képezte, hogy a fibroblasztok megfelelö tenyésztési körülmények között külső minta nélkül is képesek extracelluláris mátrix kialakítására. A betegtől nyert autológ fibroblasztok által képzett vékony irhalemezek egymásra ültetésével egy kellő vastagságú irharéteget alakítanak ki. Ezt követően a beteg hámsejtjeit ezen a bioszintetikus irhavázon tenyésztik, amíg kialakul az irharéteggel és többrétegü hámmal bíró bőrhelyettesítő. Az utolsó tíz napon a tenyésztett bőrt a tenyészmédium-levegö határ- ra kiemelve kiváltják a hámfelszín elszarusodását, így mintegy 10 hét után teljesértékü bőr átültetését tudják biztosítani [19].

További fejlesztést jelentett az azonos technikával készült, előregyártott, sejtmentes irhaváz létrehozása. Neonatalis fibroblasztok tenyésztésével alakítják ki az irhavázat, majd a fibroblasztok kimosása után $-20^{\circ} \mathrm{C}$-on tárolják. Kiolvasztás után a betegtől nyert autológ fibroblasztok és keratinociták tenyésztésére alkalmazható. Ezzel a módszerrel a bőrbiopsziától a bőrátültetésig terjedő idő 40 napra csökkenthető [20]. A 12 betegen elért rendkívüli klinikai eredményeikről nemzetközi kongresszusokon számoltak be [21].

A bemutatott eljárások az égési sérültellátás kritikus kérdéseire nyújtanak korszerü választ. Az égési sokk kezeléséhez szükséges folyadékmennyiség meghatározásában új szemléletet jelent a 10es szabály. Az átmeneti mélységü égés kezelésének megválasztásában (konzervatív vagy műtéti) minden eddiginél nagyobb segítséget jelenthet a kémiai nekrektómia elterjedése. A Suprathel jelenleg optimális megoldásnak tünik a spontán hámosodásra képes sebek ideiglenes fedése céljából, a kétrétegü, bioszintetikus autológ bőr pedig az égéssebészet legnagyobb problémájára nyújt egy ígéretes megoldást.

Véleményem szerint a hazai égési sérültellátás jelenleg igen komoly lemaradást mutat a világ élvonalához képest. A korszerü eljárások bevezetését mindenképpen célul kell tüzzük, de ezek mellett, vagy akár előtt, olyan sürgető problémák megoldását is szorgalmazni kell, mint egy égési centrum kialakítása vagy az allograft ellátás biztosítása. 


\section{Irodalom}

[1] Gillenwater, J., Garner, W.: Acute fluid management of large burns. Pathophysiology, monitoring, and resuscitation. Clin. Plast. Surg., 2017, 44: 495-503.

DOI: $10.1016 /$ j.cps.2017.02.008

[2] Pham, T.M., Cancio, L.C., Gibran, N.S.: American Burn Association Practice Guidelines burn shock resuscitation. J. Burn Care Res., 2008, 29: 257-66. DOI: 10.1097/BCR.0b013e31815f3876

[3] Saffle, J.R.: Fluid creep and over-resuscitation. Crit. Care Clin., 2016, 32: 587-98. DOI: $10.1016 /$ j.ccc.2016.06.007

[4] Chung, K.K.,Wolf, S.E.,Cancio, L.C. és mtsai: Resuscitation of severely burned military casualties: fluid begets more fluid. J. Trauma, 2009, 67: 231-7.

DOI: 10.1097/TA.0b013e3181ac68cf

[5] Caldwell, N.W., Serio-Melvin, M.L., Chung, K.K. et al.: Follow-up evaluation of the U.S. Army Institute of Surgical Research Burn Flow Sheet for en route care documentation of burned combat casualties. Mil. Med., 2017, 182: 2021-6.

DOI: 10.1097/TA.0b013e3181ac68cf

[6] Cartotto, R., Greenhalgh, D.: Colloids in acute burn resuscitation. Crit. Care Clin., 2016, 32: 507-23.

DOI: $10.1016 /$ j.ccc.2016.06.002

[7] Schulz, A., Perbix, W., Shoham, Y. et al.: Our initial learning curve in the enzymatic debridement of severely burned hands - Management and pitfalls of initial treatments and our development of a post debridement wound treatment algorithm. Burns, 2017, 43: 326-36.

DOI: 10.1016/j.burns.2016.08.009

[8] Hirche, C., Citterio, A., Hoeksema, H. et al.: Eschar removal by bromelain based enzymatic debridement (Nexobrid) in burns: An European consensus. Burns, 2017, 43: 1640-53.

DOI: 10.1016/j.burns.2017.07.025

[9] Schulz, A., Fuchs, P.C., Rothermundt, I. et al.: Enzymatic debridement of deeply burned faces: healing and early scarring based on tissue preservation compared to traditional surgical debridement. Burns, 2017, 43: 123343.

DOI: 10.1016/j.burns.2017.02.016

[10] Schulz, A., Shoham, Y., Rosenberg, L. et al.: Enzymatic versus traditional surgical debridement of severely burned hands: a comparison of selectivity, efficacy, healing time, and three-month scar quality. J. Burn Care Res., 2017, 38: 745-55. DOI: 10.1097/BCR.0000000000000478

[11] Medina, A., Riegel, T., Nystad, D. et al.:: Modified Meek micrografting technique for wound coverage in extensive burn injuries. $J$. Burn Care Res., 2016, 37: 305-13. DOI: 10.1097/BCR.0000000000000244

[12] Chong, S. J., Choke, A., Tan, B. K.: Technical tips to enhance micrografting results in burn surgery. Burns, 2017, 43: 983-986. DOI: 10.1016/j.burns.2017.01.030

[13] Rode, H., Martinez, R., Potgieter, D. et al.: Experience and outcomes of micrografting for major paediatric burns. Burns, 2017, 43: 1103-10.

DOI: 10.1016/j.burns.2017.02.008

[14]Halmy, Cs., Nádai, Z., Juhász, Zs. et al.: Bőrpótlási lehetőségek biológiai és bioszintetikus anyagokkal kiterjedt égési sérülésben. Orv. Hetil., 2008, 149: 915-919.

[15] Highton, L., Wallace, C., Shah, M.: Use of Suprathel for partial thickness burns in children. Burns, 2013, 39: 136-41. DOI: $10.1556 / \mathrm{OH} .2008 .28223$

[16] Fischer, S., Kremer, T., Horter, J.: Suprathel for severe burns in the elderly: case report and reiew of the literature. Burns, 2016, 42: 86-92.

DOI: 10.1016/j.burns.2016.05.002

[17] Hundeshagen, G., Collins, V.N., Wurzer, P. et al.: A prospective, randomized, controlled trial comparing the outpatient treatment of pediatric and adult partial-thickness burns with Suprathel or Mepilex Ag. J. Burn Care Res., 2017, 38: (epub ahead of print) DOI: 10.1097/BCR.0000000000000584

[18] Everett, M., Massand, S., Davis, W. et al.: Use of a copolymer dressing on superficial 
and partial-thickness burns in a paediatric population. J. Wound Care, 2015, 24: S4-S8. DOI: 10.12968/jowc.2015.24.Sup7.S4.

[19] Larouche, D., Cantin-Warren L., Desgagné, M. et al.: Improved methods to produce tissue-engineered skin substitutes suitable for the permanent closure of full-thickness skin injuries. Biores Open Access, 2016, 5: 320-9.

DOI: 10.1089/biores.2016.0036

[20] Beaudoin-Cloutier, C., Guignard, R., Bernard, G. et al.: Production of a bilayered self-assembled skin substitute using a tissueengineered acellular dermal matrix. Tissue Eng. Part C Methods, 2015, 21: 1297-305. DOI: 10.1089/biores.2016.0036

[21] Duranceau, L., Genest, H., Bortoluzzi, P. et al.: Successful grafting of a novel autologous tissue-engineered skin substitutes (dermis and epidermis) on twelve burn patients. J. Burn Care Res., 2014, 35: S121.

\section{Col. Cs. Halmy MDMC}

\section{New methods in acute burn surgery}

Author provides a review on hot topics in burn surgery, like fluid resuscitation, enzymatic débridement, temporal and permanent skin substitution.

Keywords: burn shock, fluid resuscitation, enzymatic débridement, skin replacement

Dr. Halmy Csaba o. ezds. 1134 Budapest, Róbert Károly krt. 44. 